\title{
Applying stable isotope probing of phospholipid fatty acids and rRNA in a Chinese rice field to study activity and composition of the methanotrophic bacterial communities in situ
}

\author{
Qiongfen Qiu ${ }^{1,2}$, Matthias Noll ${ }^{2,3}$, Wolf-Rainer Abraham ${ }^{4}$, Yahai $\mathrm{Lu}^{1}$ and Ralf Conrad ${ }^{2}$ \\ ${ }^{1}$ College of Resources and Environmental Sciences, China Agricultural University, Beijing, China; ${ }^{2}$ Max \\ Planck Institute for Terrestrial Microbiology, Marburg, Germany; ${ }^{3}$ Federal Institute for Materials Research \\ and Testing, FG IV.I, Berlin, Germany and ${ }^{4}$ Helmhotz Center for Infection Research, Chemical Microbiology, \\ Braunschweig, Germany
}

\begin{abstract}
Methanotrophs in the rhizosphere play an important role in global climate change since they attenuate methane emission from rice field ecosystems into the atmosphere. Most of the $\mathrm{CH}_{4}$ is emitted via transport through the plant gas vascular system. We used this transport for stable isotope probing (SIP) of the methanotrophs in the rhizosphere under field conditions and pulselabelled rice plants in a Chinese rice field with $\mathrm{CH}_{4}\left(99 \%{ }^{13} \mathrm{C}\right)$ for 7 days. The rate of ${ }^{13} \mathrm{CH}_{4}$ loss rate during ${ }^{13} \mathrm{C}$ application was comparable to the $\mathrm{CH}_{4}$ oxidation rate measured by the difluoromethane inhibition technique. The methanotrophic communities on the roots and in the rhizospheric soil were analyzed by terminal-restriction fragment length polymorphism (T-RFLP), cloning and sequencing of the particulate methane monooxygenase (pmoA) gene. Populations of type I methanotrophs were larger than those of type II. Both methane oxidation rates and composition of methanotrophic communities suggested that there was little difference between urea-fertilized and unfertilized fields. SIP of phospholipid fatty acids (PLFA-SIP) and rRNA (RNA-SIP) were used to analyze the metabolically active methanotrophic community in rhizospheric soil. PLFA of type I compared with type II methanotrophs was labelled more strongly with ${ }^{13} \mathrm{C}$, reaching a maximum of 6.8 atom-\%. T-RFLP analysis and cloning/sequencing of 16S rRNA genes showed that methanotrophs, especially of type I, were slightly enriched in the 'heavy' fractions. Our results indicate that $\mathrm{CH}_{4}$ oxidation in the rice rhizosphere under in situ conditions is mainly due to type I methanotrophs. The ISME Journal (2008) 2, 602-614; doi:10.1038/ismej.2008.34; published online 3 April 2008 Subject Category: microbial population and community ecology

Keywords: methane-oxidizing bacteria; rice field; rhizosphere; stable isotope probing; phospholipid fatty acid; particulate methane monooxygenase
\end{abstract}

\section{Introduction}

Flooded rice fields, an important source of atmospheric methane, are widely distributed in China (Cai, 1997; Li et al., 2002; Cai et al., 2003). The total emission of $\mathrm{CH}_{4}$ from Chinese rice fields was estimated to be in the range of $8.05 \pm 3.69 \mathrm{Tg} \mathrm{CH}_{4}$ per year, depending on the type of rice paddy field (Cai, 1997). In these ecosystems, the main $\mathrm{CH}_{4}$ emission to the atmosphere occurs through the

Correspondence: R Conrad, Max Planck Institute for Terrestrial Microbiology, Karl-von-Frisch-Strasse, Marburg D-35043, Germany. E-mail: conrad@mpi-marburg.mpg.de

Received 10 January 2008; revised 3 March 2008; accepted 3 March 2008; published online 3 April 2008 aerenchyma system of the rice plants (Nouchi et al., 1990; Schütz et al., 1991). In turn, oxygen from the atmosphere is transported to the rice roots enabling aerobic and microaerophilic conditions in the rhizosphere (Liesack et al., 2000). Aerobic methanotrophs in such rice rhizosphere environments play an important role in $\mathrm{CH}_{4}$ emission, since they attenuate the $\mathrm{CH}_{4}$ flux from the soil into the atmosphere covering a large range between 0 and 94\% attenuation (Schütz et al., 1989; Groot et al., 2003). The activity of aerobic methanotrophs strongly depends on the environmental conditions, for example the in situ concentrations of not only $\mathrm{CH}_{4}$ and $\mathrm{O}_{2}$, but also of other compounds, such as ammonium, sulfide or ferrous iron. The latter compounds can also be microbially oxidized in the 
rhizosphere resulting in competition with methanotrophs for oxygen. Ammonia oxidizers may affect $\mathrm{CH}_{4}$ oxidation due to the similarity between the key enzymes catalyzing the first step of $\mathrm{CH}_{4}$ oxidation and ammonium oxidation (Mancinelli, 1995). In previous studies, inhibition (Bosse et al., 1993; Nold et al., 1999), stimulation (Bodelier et al., 2000; Eller and Frenzel, 2001) or no effect (Lilkanen and Martikainen, 2003) on aerobic methanotrophs were observed in anoxic soils and sediments when fertilized with ammonium or urea (see review by Bodelier and Laanbroek, 2004). Another important factor for $\mathrm{CH}_{4}$ emission is the composition of the methanotrophic communities, which seem to be different in bulk soil and rhizosphere and change dynamically over the season and upon fertilization with ammonium or urea (Bodelier et al., 2000; Eller and Frenzel, 2001; Macalady et al., 2002; Eller et al., 2005; Shrestha et al., 2008).

A further complication is the fact that not all members of the total methanotrophic community are equally active in attenuation of the $\mathrm{CH}_{4}$ flux. Pulse labelling of rice plants with ${ }^{13} \mathrm{C}$ followed by stable isotope probing (SIP) of nucleic acid and membrane lipids has been demonstrated as a powerful approach to identify the metabolically active microbial communities in the rhizosphere of rice ( $\mathrm{Lu}$ and Conrad, 2005; Lu et al., 2006, 2007). SIP allows direct observations of substrate assimilation in minimally disturbed communities, and thus represents an exciting tool for linking microbial identity and function. As methanotrophs use $\mathrm{CH}_{4}$ as carbon source, SIP of phospholipid fatty acids (PLFAs) (Boschker et al., 1998; Boschker and Middelburg, 2002) or DNA/RNA (McDonald et al., 2005) using ${ }^{13} \mathrm{C}$-labelled $\mathrm{CH}_{4}$ is a promising approach. Recently, rice microcosms were used to identify the methanotrophs actively assimilating $\mathrm{CH}_{4}$-carbon that was introduced into the rice rhizosphere by means of permeable tubings (Shrestha et al., 2008). However, a labelling approach under field conditions has not been conducted, and therefore the ability to compare laboratory-based results is still lacking.

Therefore, we applied SIP in a Chinese rice field by pulse labelling the rice plants with ${ }^{13} \mathrm{C}$-labelled $\mathrm{CH}_{4}$ through the aerenchyma systems of the rice plants into the rhizosphere. This enables an in situ labelling of methanotrophs located directly at the rice rhizosphere without disturbing the soil ecosystem. Furthermore, we tested if typical Chinese farm fertilization procedures had an effect on methanotrophic activity and on the global methane emission budget from this environment.

\section{Materials and methods}

Study site and treatments

The experimental field was located at the China National Rice Research Institute (CNRRI; Hangzhou, Zhejiang province, China; $\left.30^{\circ} 25^{\prime} \mathrm{N}, 120^{\circ} 18^{\prime} \mathrm{E}\right)$. The fields cover an area of 494 ha, representing a typical rice growing area with annual single- and doublerice cropping systems. The climate is warm/cool humid subtropical with an annual rainfall of $1400 \mathrm{~mm}$ and a mean solar radiation of $12.8 \mathrm{MJ} \mathrm{m}^{-2}$ day $^{-1}$.

The field had been treated according to the common agricultural practice of the region. Fertilizers were applied directly to the rhizosphere of rice plants at the rates of $0.09 \mathrm{~g} \mathrm{P}$ and $0.41 \mathrm{~g} \mathrm{~K}$ per plant and additional $0.6 \mathrm{~g}$ urea at 48 days after transplantation. For our study, urea treatment (PKN) was done in the same field, but separated with four rows of rice plants from those plots that were only fertilized with PK. The water level was kept constant at 5-10 cm depth. The field plots were shaded with transparent black fiber tissue to avoid excessively high solar radiation during our experiment to reduce the evaporation inside the gas chambers. The soil is a silty clay soil with a $\mathrm{pH}$ of 6.7 , organic $\mathrm{C}$ of $24.2 \mathrm{~g}$ per $\mathrm{kg}$ soil, total $\mathrm{N}$ of $2.3 \mathrm{~g}$ per $\mathrm{kg}$ soil and cation exchange capacity of $144 \mathrm{mmol}$ per $\mathrm{kg}$ soil.

\section{Methane flux measurement}

Methane flux was measured on 4 consecutive days starting 3 days after fertilization. The measurements were always done between 12:00 and 16:00 hours local time. The cylindrical flux chambers (diameter $=5 \mathrm{~cm}$ and height $=40 \mathrm{~cm}$ ) were made of plexiglas. For flux measurements, rice plants were covered for a period of $4 \mathrm{~h}$ and gas samples were withdrawn every $30 \mathrm{~min}$. Methane emission rates were determined from the slope of the linearly increasing $\mathrm{CH}_{4}$ mixing ratio using a gas chromatograph with flame ionization detector.

Loss rates of ${ }^{13} \mathrm{CH}_{4}$ were determined after injection of $1 \mathrm{ml}$ of ${ }^{13} \mathrm{C}$-labelled $\mathrm{CH}_{4}$ (99 atom- $\%{ }^{13} \mathrm{CH}_{4}$; Sigma, Taufkirchen, Germany) into the flux chamber. The amount of ${ }^{13} \mathrm{CH}_{4}$ at time $t\left(n_{t}\right)$ was calculated by:

$$
n_{t}=m_{t}\left(a_{t}-a_{p}\right)
$$

$m_{t}=$ total amount of $\mathrm{CH}_{4}$ at time $t ; a_{t}={ }^{13} \mathrm{C}$ atom- $\%$ of $\mathrm{CH}_{4}$ at time $t ; a_{p}=$ natural ${ }^{13} \mathrm{C}$ atom- $\%$ of $\mathrm{CH}_{4}$. The ${ }^{13} \mathrm{C}$ atom- $\%$ was analyzed using a gas chromatography-combustion-isotope ratio mass spectrometry as described previously (Conrad et al., 2002).

The rate of $\mathrm{CH}_{4}$ oxidation was determined by measuring the $\mathrm{CH}_{4}$ flux in the presence and absence of difluoromethane $\left(20 \mathrm{ml} \mathrm{CH}_{2} \mathrm{~F}_{2}\right)$, an inhibitor of $\mathrm{CH}_{4}$ oxidation (Miller et al., 1998), which was injected into the flux chamber. The measurements were done as described by Krüger et al. (2001). It was made sure that the concentration of $\mathrm{CH}_{2} \mathrm{~F}_{2}$ did not decrease over the 4-h incubation time. Methane oxidation rates were calculated by

$$
\begin{aligned}
\text { Oxidation rate }= & \text { Emission rate inhibited } \\
& - \text { Emission rate control }
\end{aligned}
$$


The rates of the flux measurements are expressed in mmol $\mathrm{CH}_{4}$ per $\mathrm{m}^{2}$ per $\mathrm{h}$ giving the mean \pm s.e. of $n=4$ data obtained on 4 consecutive days.

\section{${ }^{13} \mathrm{C}$-labelling and sampling procedures}

Labelling with ${ }^{13} \mathrm{CH}_{4}$ was started $36 \mathrm{~h}$ after fertilization. Plots were covered with closed chambers as described above. For both the N-fertilized (PKN) and the unfertilized (PK) plots the following experiments were performed: (1) rice plants were cut so that stubbles were $15 \mathrm{~cm}$ above the water surface and $15 \mathrm{ml}$ of ${ }^{13} \mathrm{CH}_{4}$ (99 atom-\% ${ }^{13} \mathrm{CH}_{4}$; Sigma) was added to the chamber twice a day $\left({ }^{13} \mathrm{CH}_{4} \mathrm{cut}\right)$. (2) Rice plants were left intact and treated as above $\left({ }^{13} \mathrm{CH}_{4}\right)$. (3) Rice plants were left intact and treated with $15 \mathrm{ml}$ of unlabelled $\mathrm{CH}_{4}\left({ }^{12} \mathrm{CH}_{4}\right)$. (4) Rice plants were left intact and no $\mathrm{CH}_{4}$ was injected into the chamber (air). At the end of 7-day labelling, the chambers were removed and the rice plants were pulled out. Four replicates were taken in each treatment. The bulk soil fell off the roots during plant tiller separation and with gentle shaking. The soil still adhering to the roots was defined as rhizospheric soil. After cutting off the shoots, the roots with the adhering soil were separated into three batches and immediately frozen in liquid nitrogen and stored at $-80{ }^{\circ} \mathrm{C}$. Transport to laboratories in Beijing (PLFA extraction) and Marburg (DNA/RNA extraction) was done within $20 \mathrm{~h}$ keeping the samples in a frozen state.

Phospholipid fatty acid extraction and ${ }^{13} \mathrm{C}$ profiling After thawing one batch of the soil-roots samples for each replicate treatment, the soil was carefully washed from roots with deionized sterile water. The soil slurries were collected separately and centrifuged at $950 \mathrm{~g}$. Total PLFA was extracted from $4 \mathrm{~g}$ fresh soil samples using the Bligh-Dyer method (Bligh and Dyer, 1969). The total amount of PLFA was determined by gas chromatography-mass spectrometry and the stable isotope ratio of individual fatty acid methyl esters by gas chromatographycombustion-isotope ratio mass spectrometry as described by Lu et al. (2007).

The relative amounts of individual fatty acid methyl esters were calculated on the basis of the amount of PLFA 16:0. This PLFA was chosen as it is ubiquitous in prokaryotes. The fractional abundance (F) of ${ }^{13} \mathrm{C}$ in the unlabelled $\left(\mathrm{F}_{\mathrm{u}}\right)$ and labelled $\left(\mathrm{F}_{1}\right)$ PLFAs was used to calculate the concentration of ${ }^{13} \mathrm{C}$ incorporated into PLFAs ([PLFA- $\left.\left.{ }^{13} \mathrm{C}\right]\right)$ from the total PLFA concentration ([PLFA]):

$$
\left[\mathrm{PLFA}-{ }^{13} \mathrm{C}\right]=\left(F_{\mathrm{u}}-F_{\mathrm{l}}\right)[\mathrm{PLFA}]
$$

The fractional abundance expresses the amount of ${ }^{13} \mathrm{C}$ as a proportion of the total amount of carbon in the PLFA:

$$
F={ }^{13} \mathrm{C} /\left({ }^{12} \mathrm{C}+{ }^{13} \mathrm{C}\right)
$$

$D N A$ extraction and pmoA gene T-RFLP analysis After thawing another batch of the soil-roots samples for each replicate treatment, the soil was carefully washed from roots with deionized sterile water. The soil slurries were collected separately and centrifuged at $950 \mathrm{~g}$ and used for nucleic acid extraction. DNA was extracted from rhizospheric soil according to Lueders et al. (2004) with minor modifications during the precipitation step. DNA was precipitated from the aqueous phase with 1 volume isopropanol and centrifugation at maximum speed $(21000 \mathrm{~g})$ at $4{ }^{\circ} \mathrm{C}$ for $1 \mathrm{~h}$. The precipitate was washed once with $500 \mu$ l of pre-cooled $70 \%$ ethanol, dried and re-suspended in $50 \mu \mathrm{l}$ of PCR water (Sigma-Aldrich). Additional purification was done using a DNA clean-up system (Promega, Mannheim, Germany). Amplification of the particulate methane monooxygenase ( $p m o A)$ gene was performed using the primer sets 189f/682r and 189f-FAM/mb661r using nested PCR (Horz et al., 2005). Purified amplicons were digested by MspI (HpaII) (Fermentas, St Leon-Rot, Germany) at $37^{\circ} \mathrm{C}$ for $3 \mathrm{~h}$ and inactivated at $65^{\circ} \mathrm{C}$. Aliquots of desalted digest (1-2 $\mu \mathrm{l})$ were mixed with $12 \mu \mathrm{l}$ of Hi-Di formamide (Applied Biosystems, Weiterstadt, Germany) and $0.25 \mu \mathrm{l}$ of ROX-labelled MapMarker 1000 ladder (BioVentures, Murfreesboro, TN, USA), denaturated for $3 \mathrm{~min}$ at $95{ }^{\circ} \mathrm{C}$, cooled on ice immediately and size separated on an ABI 310 genetic analyzer (Applied Biosystems). Electrophoresis was performed with POP-4 polymer in $47 \mathrm{~cm}$ by $50 \mu \mathrm{m}$ capillaries (Applied Biosystems) with $15 \mathrm{kV}$ injection voltage, $15 \mathrm{kV}$ run voltage, $60{ }^{\circ} \mathrm{C}$ run temperature and $45 \mathrm{~min}$ analysis time. The peak heights were automatically quantified by the GeneScan software. The relative abundance of individual terminal-restriction fragments (T-RFs) were calculated based on the peak height of the individual T-RFs in relation to the total peak height of all T-RFs detected in the respective terminal-restriction fragment length polymorphism (T-RFLP) community pattern.

\section{RNA extraction and gradient centrifugation}

Total RNA was extracted from the rhizospheric soil samples ${ }^{13} \mathrm{CH}_{4}$ cut $+\mathrm{PKN}$ and ${ }^{12} \mathrm{CH}_{4}$ cut $+\mathrm{PKN}$ using a previously described protocol (Noll et al., 2005). RNA for reverse transcription (RT)-PCR was obtained by removal of co-extracted DNA using RNaseFree DNase (Promega) following the manufacturer's protocol. Additional RNasin (Promega) was added to inhibit RNases. The RNA pellets were resuspended in $50 \mu \mathrm{l}$ nuclease-free water (Promega). The absence of DNA in the resulting small-subunit ribosomal RNA (16S rRNA) preparation was checked by PCR of bacterial 16S rRNA genes and standard agarose gel electrophoresis on a $1 \%$ agarose followed by ethidium bromide staining. RiboGreen (500 ng; Invitrogen, Karlsruhe, Germany) was used to quantify RNA content in the extracts. 
The RNA was density resolved by equilibrium density gradient centrifugation in CsTFA (cesium trifluoroacetate) (Amersham Biosciences, Freiburg, Germany) under the conditions reported previously (Lueders et al., 2004). After centrifugation, the density of the collected gradient fractions was determined refractometrically, and RNA was precipitated and re-suspended in $30 \mu \mathrm{l}$ nuclease-free water for subsequent community analyses. Control gradients were conducted with RNA from unlabelled soil $\left({ }^{12} \mathrm{CH}_{4}\right.$ cut-PKN).

\section{RT-PCR of bacterial $16 S$ rRNA gene and T-RFLP analysis}

Terminal-restriction fragment length polymorphism analysis of density-resolved bacterial communities from gradient fractions was performed with primers Ba27f-FAM/Ba907r by RT-PCR using a one-step RTPCR system (Access Quick1 RT-PCR-System; Promega). The reaction mixture $(50 \mathrm{ml})$ contained $25 \mathrm{ml}$ of $2 \times$ reaction buffer, $0.5 \mathrm{mM}$ of each primer (MWG Biotech, Ebersberg, Germany), $1.0 \mu \mathrm{l}$ of template RNA and $1 \mu \mathrm{l}(5 \mathrm{U})$ of AMV reverse transcriptase supplied by the manufacturer. The $2 \times$ reaction buffer included $3 \mathrm{mM} \mathrm{MgSO}_{4}$ (final concentration $1.5 \mathrm{mM}$ ), Tfl DNA polymerase (unknown amount) and the deoxynucleoside triphosphates (concentration was not provided by the manufacturer). The RT reaction was carried out at $48{ }^{\circ} \mathrm{C}$ for $45 \mathrm{~min}$ and followed by a denaturing step at $94^{\circ} \mathrm{C}$ for 2 min to inactivate the AMV reverse transcriptase and to activate the Tfl DNA polymerase. The thermal profile of the PCR included 25-30 cycles of primer annealing at $52{ }^{\circ} \mathrm{C}$ for $45 \mathrm{~s}$, primer extension at $68{ }^{\circ} \mathrm{C}$ for $1 \mathrm{~min}$ and denaturing at $94^{\circ} \mathrm{C}$ for $45 \mathrm{~s}$. The final elongation step was $5 \mathrm{~min}$. Amplicons were digested by $M s p I$ and separated as described above for the pmoA gene. To verify the assignments of T-RFs to our detected methanotrophs, we also tested individual methanotrophic clones indicated in sequence data by T-RFLP analysis.

\section{Cloning, sequencing and phylogenetic analysis}

Four clone libraries were created, one of pmoA genes from sample ${ }^{13} \mathrm{CH}_{4}$ cut + PKN (54 clones) and three of bacterial 16S rRNA genes from densityresolved 'heavy' (HM) (101 clones) and 'light' (LM) RNA fractions (74 clones) and control (CM) (78 clones) as indicated in Figure 5. Amplicons for sequence analyses were generated with the same primers and PCR conditions as described above and cloned into Escherichia coli using the pGEM-T Vector System (Promega). The randomly selected clones were sequenced by the ADIS DNA core facility (Max Planck Institute for Plant Breeding Research, Cologne, Germany) on an ABI Prism 3700 sequencer (Applied Biosystems) using BigDye terminator cycle sequencing chemistry. Raw sequence data were assembled and checked with DNAStar
(Madison, WI, USA). All sequences were compared with those in the public databases by using NCBI megaBlast and the highest matched sequences were obtained from GenBank database (http://www.ncbi. nih.gov). Chimeras were checked for with the Bellerophon server (http://foo.maths.uq.edu.au/ huber/doc/doc.html) (Huber et al., 2004) for all sequences and chimera sequences were excluded for further analysis. Phylogenetic analysis were conducted using the ARB software package (Ludwig et al., 2004). A neighbor-joining tree was calculated for bacterial 16S rRNA gene sequences including a $50 \%$ base frequency filter. Neighbour-joining, maximum likelihood and tree-puzzle programs were used for calculating $p m o A$-based phylogenetic trees in which all showed the same topology.

Sequence data have been submitted to EMBL under accession numbers AM909841 to AM910093 for 16S rRNA gene and AM910094 to AM910147 for pmoA gene.

\section{Results}

Methane oxidation activity

We fertilized two plots of the same rice field with either phosphorous and potassium (PK treatment) or with phosphorous, potassium and nitrogen (PKN treatment) using the fertilization procedure typical for Chinese agriculture. Nine days after fertilization, ammonia concentrations in bulk soil were two times higher in the PKN treatment $(27.6 \pm 0.7 \mathrm{mg} \mathrm{N}$ per $\mathrm{kg}$ dry soil) compared with the PK treatment $(11.5 \pm 0.4 \mathrm{mg} \mathrm{N}$ per kg dry soil), while nitrate concentrations were low in both treatments $(0.6 \pm 0.1$ and $1.1 \pm 0.1 \mathrm{mg} \mathrm{N}$ per $\mathrm{kg}$ dry soil, respectively). Three to seven days after fertilization, $\mathrm{CH}_{4}$ emission flux from the rice field plots was measured using the closed chamber technique. The flux was measured in the presence and absence of difluoromethane $\left(\mathrm{CH}_{2} \mathrm{~F}_{2}\right)$ as specific inhibitor of methanotrophs (Miller et al., 1998), the difference being the rate of $\mathrm{CH}_{4}$ oxidation (Table 1). Both $\mathrm{CH}_{4}$ oxidation activity and the loss of ${ }^{13} \mathrm{CH}_{4}$ in the chambers to which ${ }^{13} \mathrm{C}$-labelled $\mathrm{CH}_{4}$ was added indicate that about $2-18 \%$ of the produced $\mathrm{CH}_{4}$ was oxidized (Table 1). The rates of $\mathrm{CH}_{4}$ oxidation or ${ }^{13} \mathrm{CH}_{4}$ loss were on the same order of magnitude irrespectively of whether the fields were fertilized with urea or not.

Table 1 Methane fluxes in rice field without (PK) and with (PKN) nitrogen fertilization; mean \pm s.e., $n=3-4$

\begin{tabular}{lcr}
\hline $\mathrm{CH}_{4}$ flux $\left(\mathrm{mmol}\right.$ per $\mathrm{m}^{2}$ per $\left.\mathrm{h}\right)$ & $P K$ & \multicolumn{1}{c}{$P K N$} \\
\hline $\mathrm{CH}_{4}$ emission rate & $8.7 \pm 1.4$ & $12.1 \pm 4.0$ \\
$\mathrm{CH}_{4}$ oxidation rate & $1.1 \pm 0.8$ & $0.3 \pm 1.2$ \\
${ }^{13} \mathrm{CH}_{4}$ loss rate & $2.0 \pm 0.3$ & $1.6 \pm 0.4$
\end{tabular}


Isotopic enrichment of PLFAs

Rhizospheric soil samples were retrieved from rice field plots after different treatments, that is, fertilization with (PKN) and without (PK) urea, cutting plants above the water surface (cut), and addition of ${ }^{13} \mathrm{CH}_{4},{ }^{12} \mathrm{CH}_{4}$ or no $\mathrm{CH}_{4}$ (air) to the headspace of the flux chambers. Cutting plants above the water surface does not impede the $\mathrm{CH}_{4}$ flux into the atmosphere (Seiler et al., 1984; Conrad and Schütz, 1988). The relative abundance of total PLFA was very similar in all the soil samples irrespectively of the treatment. The PLFA included Gram-positive bacterial biomarkers (15:0i, 15:0a, 17:0i, cy17:0d7,8 and 10Me-16:0) and Gram-negative biomarkers

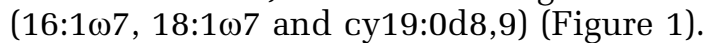

Pulsed addition of ${ }^{13} \mathrm{CH}_{4}$ into the gas headspace led to strong labelling of methanotrophic PLFAs,

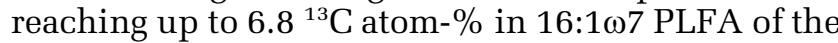
${ }^{13} \mathrm{CH}_{4}$ cut $+\mathrm{PKN}$ treatment. Mainly, the saturated and monounsaturated PLFAs with 16 and 18-carbon atoms exhibited a significant isotopic enrichment (Figure 1). Notably, the monounsaturated 16:1 107 and 16:1 166 were highly ${ }^{13} \mathrm{C}$-labelled in the PLFA profiles, which have been often affiliated to type I methanotrophs (Nold et al., 1999; Mohanty et al., 2007). Saturated $\mathrm{C}_{14}$ fatty acid, which occurs in type I Methylomonas species (Hanson and Hanson, 1996; Evershed et al., 2006), was also labelled to a less

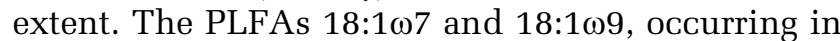
type II methanotrophs (Nold et al., 1999; Mohanty et al., 2007), were relatively strongly ${ }^{13} \mathrm{C}$-labelled, but with less intensity than the PLFAs with 16-carbon fatty acids. There was no significant difference between the plots with and without ammonium fertilization (analysis of variance, $P>0.05$ ) (Figure 1). Likewise, the treatments with and without cutting of the plants had similar isotope incorporation PLFA profiles (Figure 1). In PLFAs extracted from the unlabelled methane control soil, there was no enrichment of ${ }^{13} \mathrm{C}$ in the PLFAs.

Characterization of methanotroph communities

To characterize the functional gene diversity of the methanotrophic community, we applied pmoA gene-based T-RFLP fingerprint analysis of the different treatments after 7 days of incubation (Figure 2). Neither urea fertilization, nor addition of unlabelled or labelled $\mathrm{CH}_{4}$, nor cutting of the plants had a significant (analysis of variance, $P>0.05$ ) effect on the community structure of the T-RFLP patterns.

To assess the pmoA gene-based diversity, we cloned and sequenced in total 54 clones from pooled PCR products from all replicates of ${ }^{13} \mathrm{CH}_{4}$ cut $+\mathrm{PKN}$. This treatment was chosen for cloning, as it was also used for SIP of rRNA (RNA-SIP) (see below). Out of 54 clones, 17 represented type II methanotrophs, which clustered within the Methylocystis group (Figure 3). These type II methanotrophs represented the 244-bp T-RF. All the other T-RFs represented type I methanotrophs. Type I pmoA made up approximately $80 \%$ of the total methanotrophic community. Some (15 clones) of the pmoA clones with a $\mathrm{T}-\mathrm{RF}=79 \mathrm{bp}$, represented $p m o A$ from a group of type I methanotrophs that was distinct from pmoA from extant methanotrophs. Other clones clustered with pmoA from extant Methylococcus/ Methylocaldum, Methylomonas and Methylomicrobium/Methylobacter species (Figure 3). The T-RF of $456 \mathrm{bp}$ length occurred only with a low relative abundance $(<1 \%)$ in the T-RFLP analyses and was affiliated to members of the genus Methylomicrobium (Figure 3).

Structure of bacterial community in rhizospheric soil Ribosomal RNA was extracted from the rhizospheric soil of samples ${ }^{13} \mathrm{CH}_{4}$ cut-PKN and ${ }^{12} \mathrm{CH}_{4}$ cut-PKN, respectively. The RNA extracts were centrifuged in a density gradient and density fractions were amplified via RT-PCR with bacterial primers for subsequent T-RFLP analyses (Figure 4). Three different fractions were used to construct clone libraries of bacterial 16S rRNA, one from the control incubated with ${ }^{12} \mathrm{CH}_{4}$ (CM), one from the 'heavy' RNA (HM) and one from the 'light' RNA (LM) fraction as indicated in Figure 4. In total, 101 clones were sequenced from the HM library; 65\% were affiliated to Proteobacteria and the remaining 35\% belonged to diverse phylogenetic taxa including Actinobacteria, Firmicutes, Acidobacteria, Gemmatimonadales, Thermomicrobia, Cyanobacteria, Nitrospirae, Verrucomicrobia, Bacteroidetes and Planctomycetes (Figure 5, Table 2) (note the recent discovery of thermoacidophilic methanotrophs belonging to the Verrucomicrobia; Dunfield et al., 2007; Pol et al., 2007; Islam et al., 2008). Of the 74 clones sequenced from the LM library and the 78 clones sequenced from the CM library, 62 and $45 \%$, respectively, were affiliated to Proteobacteria. Deltaproteobacteria-like clone sequences dominated the retrieved sequences affiliated to Proteobacteria (34, 28 and 33\% in HM, LM and CM clone library, respectively). Methanotrophic bacteria within the Alphaproteobacteria and Gammaproteobacteria were relatively more frequent in the HM library than in the LM and CM clone libraries (Table 2). In silico prediction of T-RF sizes from sequence data (Table 2) allowed the assignment of the major T-RFs observed in the bacterial fingerprints (Figure 5).

\section{Metabolically active methanotrophic community} The comparison between 16S rRNA T-RFLP fingerprinting and clone libraries indicated a relative increase of the 150-bp, 455-bp and 487-bp T-RFs in the 'heavy' compared with the other RNA fractions (Figure 4). The T-RFLP patterns are in agreement with the higher abundance of methanotrophs in the HM versus the LM and CM clone libraries (Table 2). Thus, it seems that methanotrophs were enriched in 

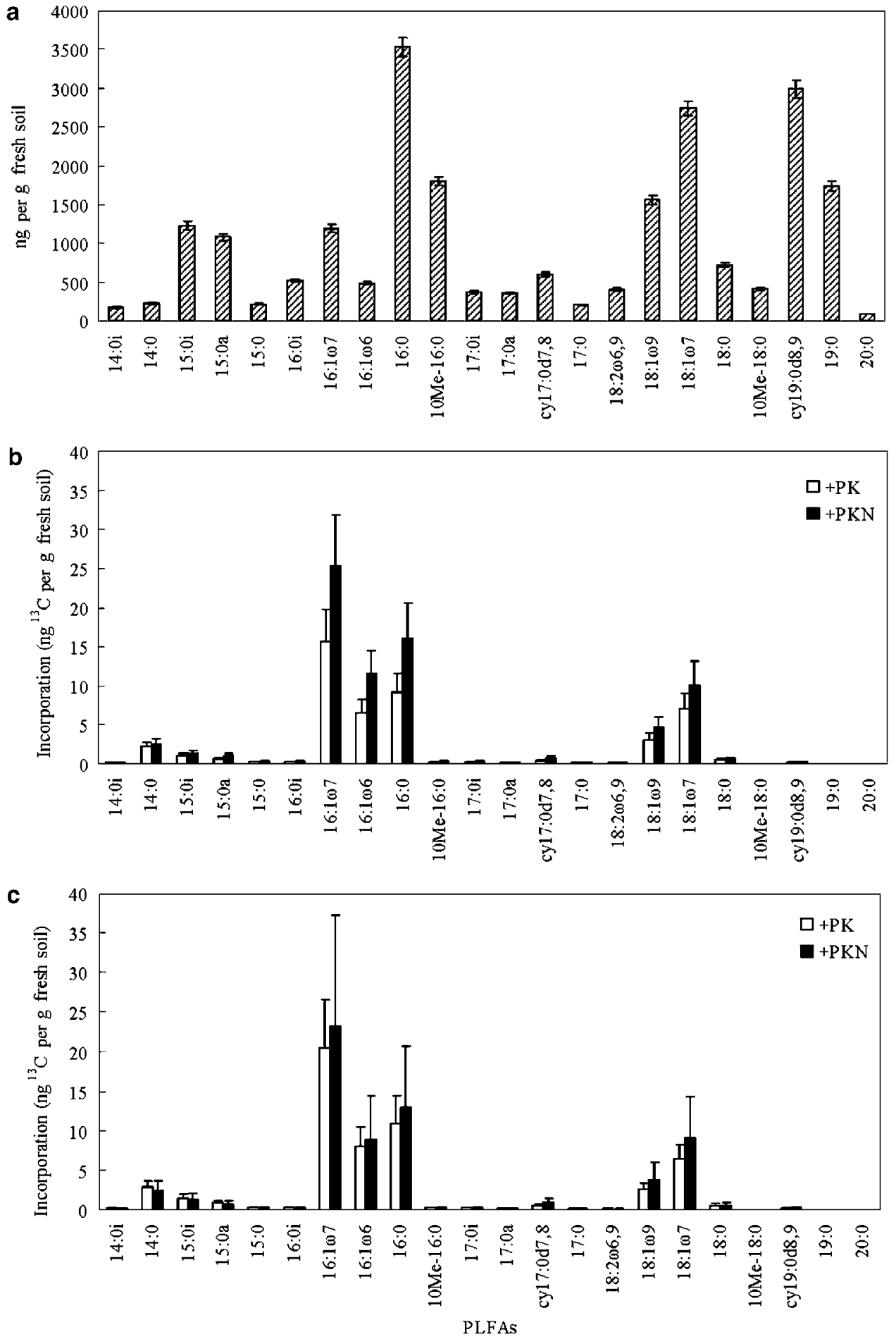

Figure 1 (a) Concentrations of individual phospholipid fatty acids (PLFAs) at the end of the field experiment using samples from all the different treatments including $\mathrm{N}$ fertilization and cutting of plants; mean \pm s.e., $n=32$. The small error bars show that concentrations of PLFAs were similar in the different treatments. (b and $\mathbf{c}$ ) Concentrations of ${ }^{13} \mathrm{C}$-labelled PLFA in the soil at the end of the field experiment with (PKN) and without (PK) addition of $\mathrm{N}$ fertilizer on plots with (b) intact plants and (c) plants cut above the water surface, both labelled with ${ }^{13} \mathrm{CH}_{4}$; mean \pm s.e.; $n=4$.

the 'heavy' fraction. The T-RFs of 455 and $487 \mathrm{bp}$ represented type I methanotrophs. Only Methylosarcina and Methylomicrobium had a T-RF $=487 \mathrm{bp}$ when considering all the bacterial $16 \mathrm{~S}$ rRNA sequences retrieved (Table 2). Some of type I methanotrophs had 444-bp and 479-bp T-RFs as indicted by the HM clone library (Table 2), but these T-RFs were not seen in the T-RFLP patterns 


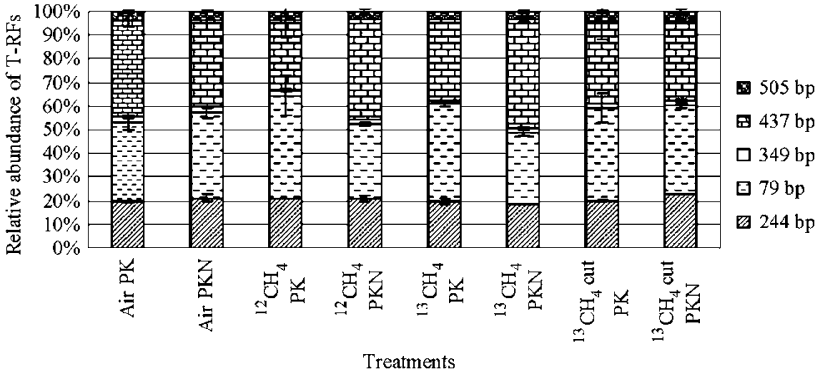

Figure 2 Relative abundance of terminal-restriction fragments (T-RFs) of particulate methane monooxygenase ( $p m o A$ ) amplicons obtained from the various treatments at the end of the field experiment. 244-bp T-RF is representative of type II methanotrophs; the others $(79,349,437$ and $505 \mathrm{bp}$ ) are representative of type I methanotrophs. PK and PKN indicates the fertilizers applied; air, ${ }^{12} \mathrm{CH}_{4}$ and ${ }^{13} \mathrm{CH}_{4}$, the gas treatment; cut indicates that plants were cut above the water surface; mean \pm s.e., $n=2$.
(Figure 4). The T-RFs of 150 bp length were mainly found in clones belonging to Methylocystis species and exhibited a significant increase in the 'heavy' fractions (Figure 4). No other type II methanotrophs were found in the 'heavy' fractions. Hence, type I methanotrophs, including Methylobacteria, Methylosarcina, Methylomicrobium and Methylomonas, seemed to be more diverse than type II methanotrophs in the 'heavy' fraction (Figure 4).

\section{Discussion}

By applying ${ }^{13} \mathrm{CH}_{4}$ to the phyllosphere of rice, we were able to identify for the first time active methanotrophs under field conditions. Both PLFASIP (SIP of phospholipid fatty acids) and RNA-SIP
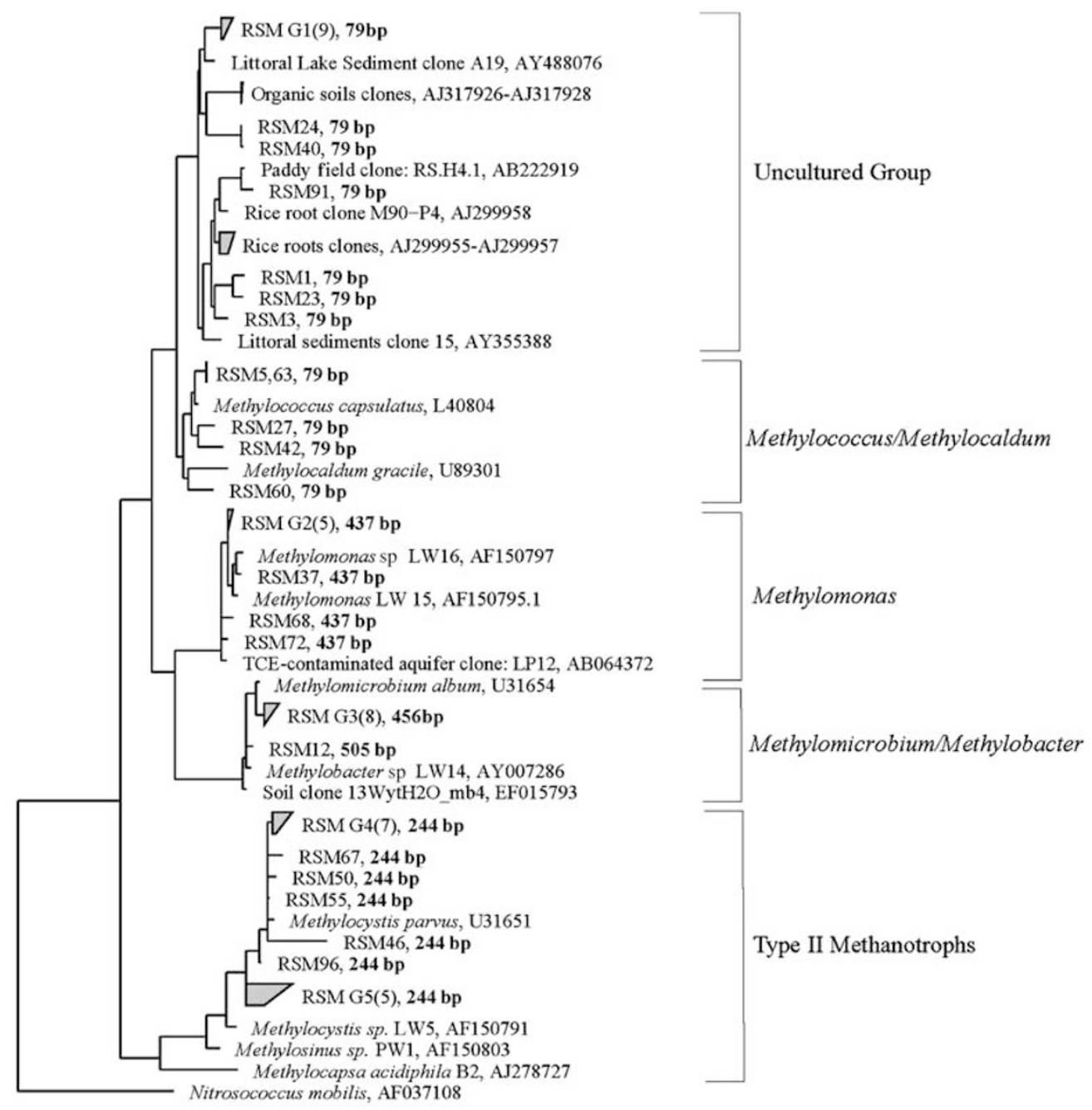

$\underline{010}$

Figure 3 Phylogenetic relationship (neighbor-joining) of amino-acid sequences derived from particulate methane monooxygenase $(p m o A)$ sequences cloned from rice soil methanotrophs (RSMs) retrieved from soil samples of the cut + PKN treatment. The terminalrestriction fragment (T-RF) sizes of clone sequences digested in silico with MspI are shown in bold. Values in parentheses give the number of clones in the indicated group. The scale bar represents $10 \%$ sequence divergence; outgroup $=a m o A$. GeneBank accession numbers of the reference sequences are indicated. 
50100150200250300350400450500550600650700750800850900
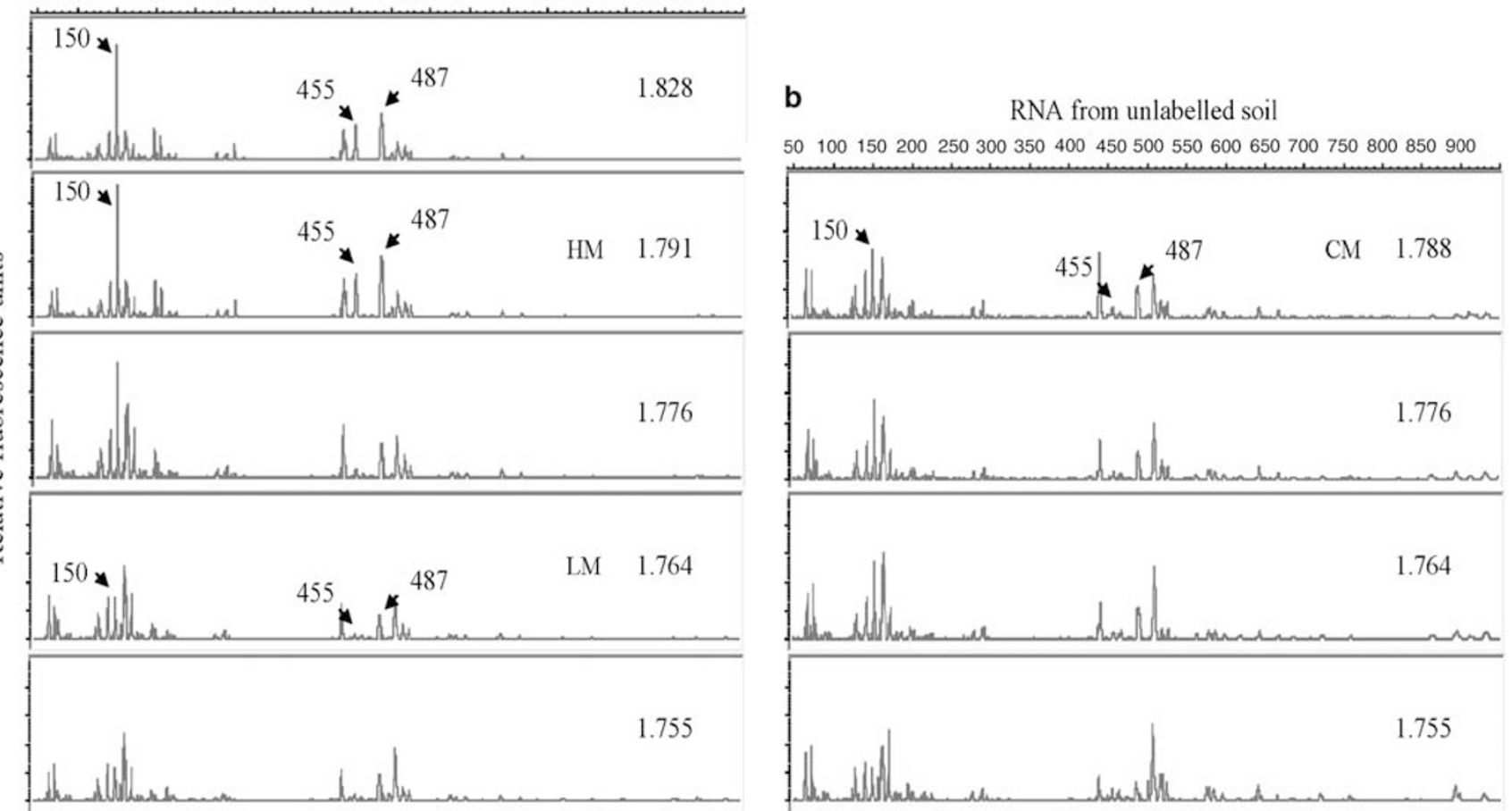

Figure 4 Bacterial terminal-restriction fragment length polymorphism (T-RFLP) fingerprints of $16 \mathrm{~S}$ rRNA retrieved from densityresolved gradient fractions of (a) ${ }^{13} \mathrm{C}$-labelled rhizospheric soil and (b) unlabelled control soil. CsTFA (cesium trifluoroacetate) buoyant densities $\left(\mathrm{g} \mathrm{ml}^{-1}\right)$ of fractions are given. The specific fragment lengths (bp) of methanotrophic T-RFs (as mentioned in the text) are indicated by arrows. HM, LM and CM indicate the fractions from which clone libraries were generated.

indicated that mainly type I methanotrophs and to a less extent type II methanotrophs assimilated $\mathrm{CH}_{4}$ in the rhizosphere.

In previous studies, $\mathrm{CH}_{4}$ was supplied to the soilplant system by the water from the bottom of rice microcosms (Groot et al., 2003) or through permeable tubes buried into the soil (Shrestha et al., 2008). Such technical approach is suitable for microcosm experiments, but can hardly be used for field studies. Since rice plants allow the transport of $\mathrm{O}_{2}$ from the atmosphere into the soil and of $\mathrm{CH}_{4}$ from the soil into atmosphere via their gas vascular system and aerenchyma tissue in roots and shoots by a diffusional process (Nouchi et al., 1990; Schütz et al., 1991), we inferred that transport of ${ }^{13} \mathrm{C}$-labelled $\mathrm{CH}_{4}$ from the atmosphere into the rhizosphere is also possible and that rhizospheric methanotrophs can be labelled in this way. The transport of ${ }^{13} \mathrm{C}$-labelled $\mathrm{CH}_{4}$ from the atmosphere into the rhizosphere was indeed operating as shown by the incorporation of ${ }^{13} \mathrm{C}$ into microbial PLFAs. Cutting plants above the water surface does not impede the $\mathrm{CH}_{4}$ flux into the atmosphere (Seiler et al., 1984; Conrad and Schütz, 1988). It apparently did also not impede the transport of ${ }^{13} \mathrm{CH}_{4}$ into the rhizosphere as microbial PLFAs were comparably labelled as with intact plants.

After labelling for 7 days, the ${ }^{13} \mathrm{C}$ content of some

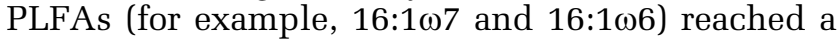
value of almost 7 atom- $\%$. Labelling experiments with ${ }^{13} \mathrm{CH}_{4}$ diffusing from permeable tubes buried into the soil achieved only about 3 atom-\% incorporation (Shrestha et al., 2008), indicating that the supply of $\mathrm{CH}_{4}$ through the plant vascular system allows a more efficient labelling of the rhizosphere microbiota. Manefield et al. (2002) determined in a pure culture that the labelling of RNA should be $>10$ atom- $\%$ to allow separation by density centrifugation. However, recent studies of plants pulse labelled with ${ }^{13} \mathrm{CO}_{2}$ showed that root-inhabiting microbes incorporated within only $5 \mathrm{~h}$ sufficient amounts of ${ }^{13} \mathrm{C}$ to allow separation of heavy RNA by density gradient centrifugation (Vandenkoornhuyse et al., 2007). This was possible although the $\delta^{13} \mathrm{C}$ content of the bulk root biomass was rather low (equivalent to 1.4 atom-\%). Although the labelled PLFAs detected in our experiments are biomarkers for a limited group of bacteria, they nevertheless represent not only methanotrophs but also other microorganisms, so that the methanotrophs might be ${ }^{13} \mathrm{C}$-labelled by $>7$ atom-\%. Therefore, we attempted RNA-SIP, which indeed was successful. The obtained results were consistent with the results of PLFA-SIP and indicated that type I methanotrophs were slightly more active in assimilation of ${ }^{13} \mathrm{CH}_{4}$ than type II methanotrophs. Hence, the application of ${ }^{13} \mathrm{CH}_{4}$ to the rice canopy seems to be a suitable technique for identification of rhizospheric methanotrophs active in $\mathrm{CH}_{4}$ oxidation. 


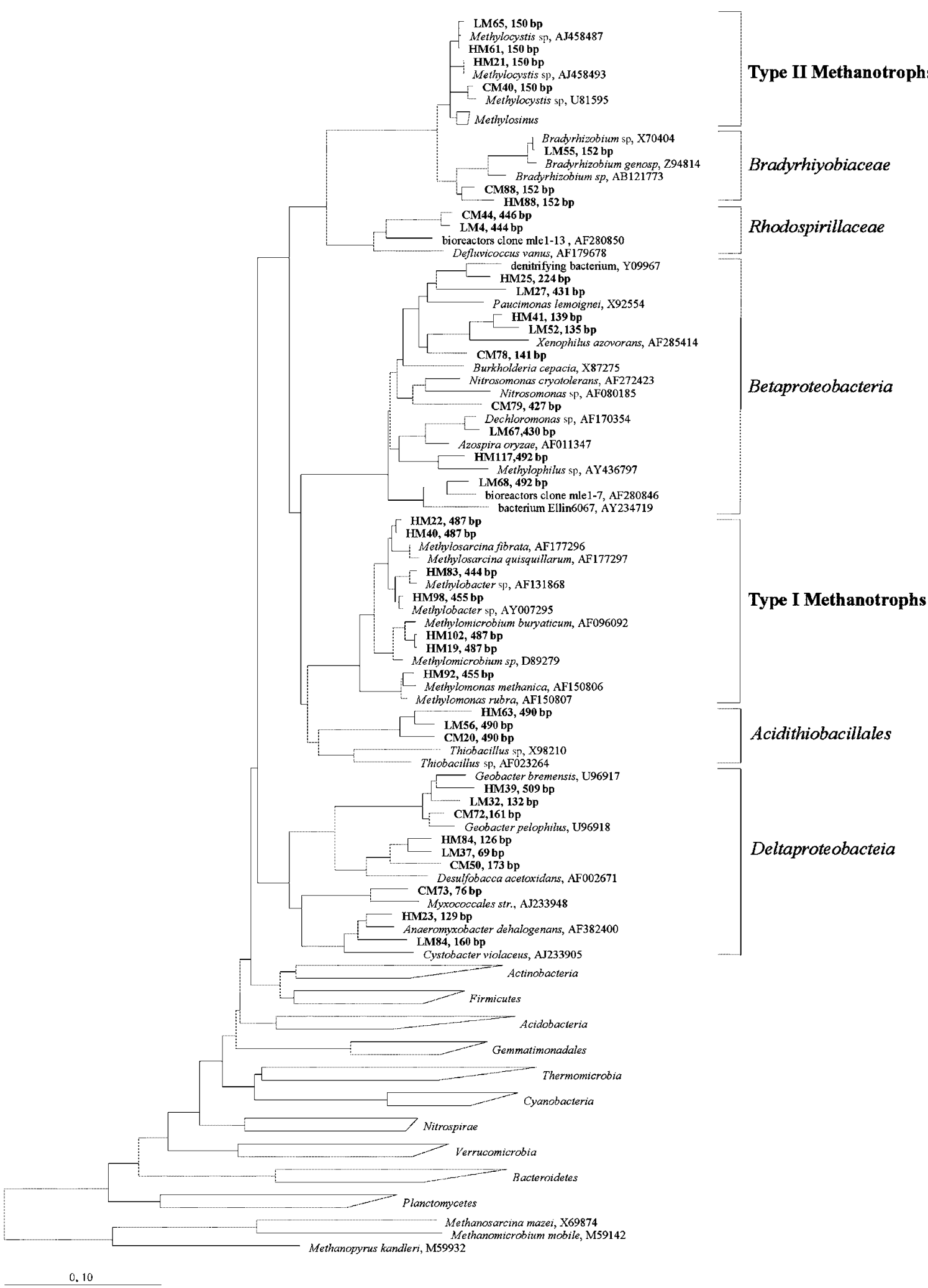

Figure 5 Phylogenetic relationship (neighbor-joining) of cloned bacterial 16S rRNA gene sequences retrieved from amplicons of the density-resolved 'heavy' (HM) and 'light' (LM) RNA fractions and from the control (CM) RNA. The new clone sequences and their terminal-restriction fragment (T-RF) sizes digested in silico with MspI are shown in bold. The scale bar represents $10 \%$ sequence divergence. GenBank accession numbers of the reference sequences are indicated. 
Table 2 Phylogenetic affiliations and numbers of 16S rRNA sequences retrieved in clone libraries generated from density-resolved RNA

\begin{tabular}{|c|c|c|c|c|c|c|c|c|c|}
\hline RNA fractions & $\begin{array}{l}\text { Heavy } \\
(H M)^{\mathrm{a}}\end{array}$ & $\%$ & $T-R F(b p)^{\mathrm{b}}$ & $\begin{array}{l}\text { Light } \\
(L M)^{\mathrm{a}}\end{array}$ & $\%$ & $T-R F(b p)^{\mathrm{b}}$ & $\begin{array}{c}{ }^{12} C \\
(C M)^{\mathrm{a}}\end{array}$ & $\%$ & $T-R F(b p)^{\mathrm{b}}$ \\
\hline \multicolumn{10}{|l|}{ Alphaproteobacteria } \\
\hline Methylocystaceae & 3 & 3 & & 2 & 2.7 & & 2 & 2.6 & \\
\hline Methylocystis & 3 & 3 & $150^{*}$ & 2 & 2.7 & 150,151 & 2 & 2.6 & $150^{*}$ \\
\hline Bradyrhizobiaceae & 1 & 1 & 152 & 4 & 5.4 & $152^{*}$ & 1 & 1.3 & 152 \\
\hline Rhodospirillaceae & & & & 4 & 5.4 & $443,64,444,113$ & 2 & 2.6 & 446,13 \\
\hline Caulobacterales & & & & 1 & 1.4 & 152 & & & \\
\hline Hyphomicrobiaceae & 1 & 1 & 150 & & & & & & \\
\hline \multicolumn{10}{|l|}{ Betaproteobacteria } \\
\hline Burkholderiales & 6 & 5.9 & $488,116^{*}, 139^{*}$ & 3 & 4.1 & $488,135,491$ & 1 & 1.3 & 141 \\
\hline Rhodocyclaceae & 7 & 6.9 & $\begin{array}{l}224,490^{*}, 430 \\
432,475,427\end{array}$ & 5 & 6.7 & $\begin{array}{l}431,490,430,82, \\
434\end{array}$ & 1 & 1.3 & 492 \\
\hline Nitrosomonadales & & & & 3 & 4.1 & $492^{*}, 490$ & 1 & 1.3 & 427 \\
\hline Methylophilaceae & 1 & 1 & 492 & & & & & & \\
\hline \multicolumn{10}{|l|}{ Gammaproteobacteria } \\
\hline Acidithiobacillales & 1 & 1 & 490 & 3 & 4.1 & $490^{*}, 227$ & 1 & 1.3 & 490 \\
\hline Methylococcaceae & 12 & 12 & & & & & & & \\
\hline Methylobacter & 2 & 2 & 444,455 & & & & & & \\
\hline Methylosarcina & 4 & 4 & $487^{*}$ & & & & & & \\
\hline Methylomicrobium & 3 & 3 & $487^{*}$ & & & & & & \\
\hline Methylomonas & 3 & 3 & $455,479^{*}$ & & & & & & \\
\hline Unknown & & & & 1 & 1.4 & 141 & 1 & 1.3 & 461 \\
\hline \multicolumn{10}{|l|}{ Deltaproteobacteria } \\
\hline Desulfobacterales & 4 & 4 & $126^{*}, 509^{*}$ & 4 & 5.4 & $173,125,69^{*}$ & 7 & 9 & $82,68^{*}, 69,173^{*}$ \\
\hline Desulfuromonadales & 12 & 12 & $\begin{array}{l}509,160,159 \\
162^{*}, 69,499^{*} \\
497,164,127^{*}\end{array}$ & 9 & 12 & $\begin{array}{l}132,160,509, \\
164,162^{*}, 166, \\
499\end{array}$ & 5 & 6.4 & $\begin{array}{l}161,129,212, \\
130,133\end{array}$ \\
\hline Syntrophobacterales & 2 & 2 & 508,509 & & & & 2 & 2.6 & $164^{*}$ \\
\hline Bdellovibrionales & & & & & & & 2 & 2.6 & $67^{*}$ \\
\hline Myxococcales & 13 & 13 & $\begin{array}{l}444,158,129 \\
155,78^{*}, 76^{*} \\
216^{*}, 183\end{array}$ & 7 & 9.5 & $\begin{array}{l}121,133,160,78 \\
216,195,498\end{array}$ & 8 & 10 & $\begin{array}{l}158,444,121^{*} \\
76,67^{*}\end{array}$ \\
\hline Unknown & 3 & 3 & $162 *, 124$ & & & & 1 & 1.3 & 162 \\
\hline Verrucomicrobia & 1 & 1 & 169 & & & & 2 & 2.6 & 169, 209 \\
\hline Acidobacteria & 9 & 8.9 & $\begin{array}{l}264,177^{*}, 283 \\
295,292^{*}, 125 \\
204\end{array}$ & 6 & 8.1 & $\begin{array}{l}201,198,141 \\
295^{*}, 124\end{array}$ & 4 & 5.1 & $201^{*}, 296^{*}$ \\
\hline Firmicutes & 1 & 1 & 530 & 3 & 4.1 & $133,519,128$ & & & \\
\hline Actinobacteria & 6 & 5.9 & $\begin{array}{l}84,67,132^{*} \\
163^{*}\end{array}$ & & & & 5 & 6.4 & $140,132^{*}, 142^{*}$ \\
\hline Nitrospirae & & & & 2 & 2.7 & 292,127 & 3 & 3.8 & $157^{*}$ \\
\hline Cyanobacteria & 7 & 6.9 & $159,154^{*}$ & 1 & 1.4 & 159 & & & \\
\hline Thermomicrobia & 9 & 8.9 & $\begin{array}{l}644,642,592 \\
650^{*}, 521,515 \\
516,518\end{array}$ & 13 & 18 & $\begin{array}{l}172,127,461^{*} \\
643^{*}, 167,521, \\
515,517^{*}\end{array}$ & 16 & 21 & $\begin{array}{l}179^{*}, 170,519 \\
169,647,511^{*} \\
515,519,163 \\
75,139^{*}\end{array}$ \\
\hline Gemmatimonadales & & & & 1 & 1.4 & 141 & 6 & 7.7 & $79 *, 122$ \\
\hline Planctomycetes & 2 & 2 & $312^{*}$ & 2 & 2.7 & 97,296 & 1 & 1.3 & 227 \\
\hline Sphingobacteria & & & & & & & 6 & 7.7 & $89^{*}$ \\
\hline Total & 101 & 100 & & 74 & 100 & & 78 & 100 & \\
\hline
\end{tabular}

Abbreviations: rRNA, ribosomal RNA; T-RF, terminal-restriction fragment.

a'Heavy (HM)' and 'Light (LM)' are samples of ${ }^{13} \mathrm{C}$ enrichment of rRNA; ${ }^{12} \mathrm{C}(\mathrm{CM})$ is control rRNA.

${ }^{\mathrm{b}} \mathrm{T}-\mathrm{RF}$ lengths are shown in base pairs (bp), T-RFs detected in more than one phylogenetic group are marked with an asterisk $\left(^{*}\right)$.

The fatty acid $16: 1 \omega 7$ received most of the ${ }^{13} \mathrm{C}-$ label in our experiment (Figure 3). This fatty acid is common not only in type I methanotrophs but also in ammonia oxidizers, even in one type II methanotroph (Dedysh et al., 2007). Although ammonia oxidizers can oxidize $\mathrm{CH}_{4}$ and contain the PLFAs 16:0 and 16:1 $\omega 7$ (Roslev and Iversen, 1999), they seem to play no role for $\mathrm{CH}_{4}$ oxidation in rice field soil (Bodelier and Frenzel, 1999). Furthermore, ammonia oxidizers may not be able to assimilate $\mathrm{CH}_{4}$ as a carbon source (Bedard and Knowles, 1989). Since the ${ }^{13} \mathrm{C}$-labelling of PLFA was similar in samples from unfertilized and urea-fertilized plots, we assume that ammonia oxidizers indeed were not involved in $\mathrm{CH}_{4}$ oxidation. A somewhat lower ${ }^{13} \mathrm{C}$ -

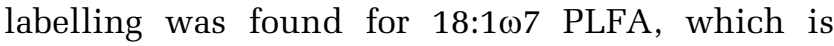


present in all known type II methanotrophs (Bowmann et al., 1993). Labelling of 18:169 PLFA, which also belongs to type II methanotroph, was still weaker. Hence, methanotophs characterized by $\mathrm{C}_{16^{-}}$ PLFAs incorporated more labelled $\mathrm{CH}_{4}$ than those characterized by $\mathrm{C}_{18}$-PLFAs, suggesting that type I methanotrophs were more active in the rhizosphere of rice than type II methanotrophs.

To assess methanotroph diversity within environmental samples, functional genes, such as $p m o A$, have also been used extensively as targets for PCR amplification (McDonald and Murrell, 1997) in rice field ecosystems (Henckel et al., 1999; Hoffmann et al., 2002; Shrestha et al., 2008). This approach has been successful with methanotrophs as their $16 \mathrm{~S}$ rRNA phylogeny is reflected in the phylogenetic relationships of pmoA (Holmes et al., 1995), with the exception of Methylocella spp, which do not contain pmoA (Dedysh et al., 2000). Thus, the analysis of $p m o A$ in our study suggested a large diversity, including Methylomonas, Methylococcus/ Methylocaldum, Methylomicrobium, Methylobacter and Methylocystis species. An uncultured group of type I methanotrophs with the same T-RF size as Methylococcus/Methylocaldum was detected in the clone libraries of pmoA. This uncultured group has formerly been detected on rice roots from Italian rice fields (Horz et al., 2001) and littoral lake sediment (Bussmann et al., 2004; Pester et al., 2004). Collectively, the $p m o A$ analyses confirmed that type I methanotrophs formed the dominant methanotrophic populations in the rice rhizosphere. However, little difference was observed between plots that were fertilized or not fertilized with urea. This was consistent with methane oxidation measurement and PLFA analysis. Possibly, urea fertilization affects on methanotrophic populations only for a short period after the treatment (Dan et al., 2001; Krüger and Frenzel, 2003). Urea is the most important nitrogen fertilizer in rice agriculture (Dedatta and Buresh, 1989).

Among the type II methanotrophs, only Methylocystis spp was detected by analysis of both pmoA and 16S rRNA genes. RNA-SIP indicated that the $\mathrm{T}-\mathrm{RF}=150 \mathrm{bp}$ increased in the 'heavy' fractions (Figure 4), which predominantly represented type II methanotrophs. Among the type I methanotrophs mainly the T-RFs of 455 and $487 \mathrm{bp}$ increased with the density fraction and were only found in the clone library from the 'heavy' but not from the 'light' or 'control' rRNA clone libraries. The relative abundance of these different T-RFs in the different fractions indicate that both type I and type II methanotrophs incorporated ${ }^{13} \mathrm{C}$ from the labelled $\mathrm{CH}_{4}$, but type I increased relatively more than type II methanotrophs (Table 3).

In conclusion, we found that SIP of methanotrophic bacteria is possible for rice fields under in situ conditions identifying individual groups of methanotrophs that are active in the rhizosphere and contribute to attenuate the emission of $\mathrm{CH}_{4}$ into
Table 3 Relative abundance of bacterial rRNA T-RFs assigned to methanotrophs

\begin{tabular}{|c|c|c|c|c|c|c|}
\hline \multirow[t]{3}{*}{ Buoyant density } & \multicolumn{6}{|c|}{ Relative abundance (\%) } \\
\hline & Type II & & & Type I & & \\
\hline & $150 \mathrm{bp}$ & $444 b p^{\mathrm{a}}$ & $455 b p$ & $479 b p^{\mathrm{a}}$ & $487 b p$ & Total \\
\hline 1.791 & 14.2 & 3.0 & 4.3 & ND & 6.0 & 13.3 \\
\hline $1.764(\mathrm{LM})$ & 4.3 & ND & 0.6 & ND & 2.3 & 2.9 \\
\hline $1.788(\mathrm{CM})$ & 7.1 & ND & 1.0 & ND & 3.2 & 4.2 \\
\hline
\end{tabular}

Abbreviations: CM, control rRNA; HM, heavy fraction rRNA; LM, light fraction rRNA, ND, not detected in T-RFLP; rRNA, ribosomal RNA; T-RF, terminal-restriction fragment; T-RFLP, terminal-restriction fragment length polymorphism.

${ }^{\text {a}}$ Not separated completely in T-RFLP

${ }^{\mathrm{b}}$ Total percentage of type I methanotroph T-RFs.

the atmosphere. It seems that type I compared with type II methanotrophs have a larger population (TRFLP of $p m o A$ gene) in the rhizosphere and are also more active in assimilating ${ }^{13} \mathrm{CH}_{4}$ into PLFA and RNA. A more precise determination, in particular by RNA-SIP, should be possible, if the production of unlabelled $\mathrm{CH}_{4}$ by the methanogenic community in the soil would be relatively low so that the pool of ${ }^{13} \mathrm{CH}_{4}$ in the rhizosphere is not much diluted. This labelling approach may be adapted to other ecosystem studies to understand ecosystem functioning without laboratory-based limitations.

\section{Acknowledgements}

We thank Esther Surges for GC and IRMS measurements, Professor Peter Frenzel (MPI) for helpful discussion and Professor Zongxiu Sun (China National Rice Research Institute) for access to the rice fields. This work was done in the framework of a Max Planck Partner Group.

\section{References}

Bedard C, Knowles R. (1989). Physiology, biochemistry, and specific inhibitors of $\mathrm{CH}_{4}, \mathrm{NH}_{4}^{+}$, and $\mathrm{CO}$ oxidation by methanotrophs and nitrifiers. Microbiol Rev 53: 68-84.

Bligh EG, Dyer WJ. (1969). A rapid method for total lipid extraction and purification. Can J Biochem Physiol 37: 911-917.

Bodelier PLE, Frenzel P. (1999). Contribution of methanotrophic and nitrifying bacteria to $\mathrm{CH}_{4}$ and $\mathrm{NH}_{4}^{+}$ oxidation in the rhizosphere of rice plants as determined by new methods of discrimination. Appl Environ Microbiol 65: 1826-1833.

Bodelier PLE, Laanbroek HJ. (2004). Nitrogen as a regulatory factor of methane oxidation in soils and sediments (Review). FEMS Microbiol Ecol 47: 265-277.

Bodelier PLE, Roslev P, Henckel T, Frenzel P. (2000). Stimulation by ammonium-based fertilizers of methane oxidation in soil around rice roots. Nature 403: 421-424. 
Boschker HTS, Middelburg JJ. (2002). Stable isotopes and biomarkers in microbial ecology (Review). FEMS Microbiol Ecol 40: 85-95.

Boschker HTS, Nold SC, Wellsbury P, Bos D, DeGraaf W, Pel R et al. (1998). Direct linking of microbial populations to specific biogeochemical processes by ${ }^{13} \mathrm{C}$-labelling of biomarkers. Nature 392: 801-805.

Bosse U, Frenzel P, Conrad R. (1993). Inhibition of methane oxidation by ammonium in the surface layer of a littoral sediment. FEMS Microbiol Ecol 13: 123-134.

Bowmann JP, Sly LI, Nichols PD, Hayward AC. (1993). Revised taxonomy of the methanotrophs: description of Methylobacter gen. nov., emendation of Methylococcus, validation of Methylosinus and Methylocystis species, and a proposal that the family Methylococcaceae includes only the group I methanotrophs. Int $J$ Syst Bacteriol 43: 735-753.

Bussmann I, Pester M, Brune A, Schink B. (2004). Preferential cultivation of type II methanotrophic bacteria from littoral sediments (Lake Constance). FEMS Microbiol Ecol 47: 179-189.

Cai ZC. (1997). A category for estimate of $\mathrm{CH}_{4}$ emission from rice paddy fields in china. Nutrient Cycling in Agroecosystems 49: 171-179.

Cai ZC, Tsuruta H, Gao M, Xu H, Wei CF. (2003). Options for mitigating methane emission from a permanently flooded rice field. Glob Chang Biol 9: 37-45.

Conrad R, Klose M, Claus P. (2002). Pathway of $\mathrm{CH}_{4}$ formation in anoxic rice field soil and rice roots determined by ${ }^{13} \mathrm{C}$-stable isotope fractionation. Chemosphere 47: 797-806.

Conrad R, Schütz H. (1988). Methods of studying methanogenic bacteria and methanogenic activities in aquatic environments. In: Austin B (ed). Methods in Aquatic Bacteriology. Wiley: Chichester. pp 301-343.

Dan JG, Krüger M, Frenzel P, Conrad R. (2001). Effect of a late season urea fertilization on methane emission from a rice field in Italy. Agric Ecosyst Environ 83: 191-199.

Dedatta SK, Buresh RJ. (1989). Integrated nitrogen management in irrigated rice. Adv Soil Sci 10: 143-169.

Dedysh SN, Belova SE, Bodelier PLE, Smirnova KV, Khmelenina VN, Chidthaisong A et al. (2007). Methylocystis heyeri sp. nov., a novel type II methanotrophic bacterium possessing 'signature' fatty acids of type I methanotrophs. Int J Syst Evol Microbiol 57: 472-479.

Dedysh SN, Liesack W, Khmelenina VN, Suzina NE, Trotsenko YA, Semrau JD et al. (2000). Methylocella palustris gen. nov., sp nov., a new methane-oxidizing acidophilic bacterium from peat bags, representing a novel subtype of serine-pathway methanotrophs. Int J Syst Evol Microbiol 50: 955-969.

Dunfield PF, Yuryev A, Senin P, Smirnova AV, Stott MB, Hou SB et al. (2007). Methane oxidation by an extremely acidophilic bacterium of the phylum Verrucomicrobia. Nature 450: 879-882.

Eller G, Frenzel P. (2001). Changes in activity and community structure of methane-oxidizing bacteria over the growth period of rice. Appl Environ Microbiol 67: 2395-2403.

Eller G, Krüger M, Frenzel P. (2005). Comparing field and microcosm experiments: a case study on methano- and methylo-trophic bacteria in paddy soil. FEMS Microbiol Ecol 51: 279-291.

Evershed RP, Crossman ZM, Bull ID, Mottram H, Dungait JAJ, Maxfield PJ et al. (2006). C-Labelling of lipids to investigate microbial communities in the environment (Review). Curr Opinion Biotechnol 17: 72-82.

Groot TT, VanBodegom PM, Harren FJM, Meijer HAJ. (2003). Quantification of methane oxidation in the rice rhizosphere using ${ }^{13} \mathrm{C}$-labelled methane. Biogeochemistry 64: 355-372.

Hanson RS, Hanson TE. (1996). Methanotrophic bacteria. Microbiol Rev 60: 439-471.

Henckel T, Friedrich M, Conrad R. (1999). Molecular analyses of the methane-oxidizing microbial community in rice field soil by targeting the genes of the $16 \mathrm{~S}$ rRNA, particulate methane monooxygenase, and methanol dehydrogenase. Appl Environ Microbiol 65: 1980-1990.

Hoffmann T, Horz HP, Kemnitz D, Conrad R. (2002). Diversity of the particulate methane monooxygenase gene in methanotrophic samples from different rice field soils in China and the Philippines. Syst Appl Microbiol 25: 267-274.

Holmes AJ, Costello A, Lidstrom ME, Murrell JC. (1995). Evidence that particulate methane monooxygenase and ammonia monooxygenase may be evolutionarily related. FEMS Microbiol Lett 132: 203-208.

Horz HP, Rich V, Avrahami S, Bohannan BJM. (2005). Methane-oxidizing bacteria in a California upland grassland soil: diversity and response to simulated global change. Appl Environ Microbiol 71: 2642-2652.

Horz HP, Yimga MT, Liesack W. (2001). Detection of methanotroph diversity on roots of submerged rice plants by molecular retrieval of pmoA, mmoX, mxaF, and $16 \mathrm{~S}$ rRNA and ribosomal DNA, including $p m o A$ based terminal restriction fragment length polymorphism profiling. Appl Environ Microbiol 67: 4177-4185.

Huber T, Faulkner G, Hugenholtz P. (2004). Bellerophon: a program to detect chimeric sequences in multiple sequence alignments. Bioinformatics 20: 2317-2319.

Islam T, Jensen S, Reigstad LJ, Larsen O, Birkeland NK. (2008). Methane oxidation at $55^{\circ} \mathrm{C}$ and $\mathrm{pH} 2$ by a thermoacidophilic bacterium belonging to the Verrucomicrobia phylum. Proc Natl Acad Sci USA 105: 300-304.

Krüger M, Frenzel P. (2003). Effects of N-fertilisation on $\mathrm{CH}_{4}$ oxidation and production, and consequences for $\mathrm{CH}_{4}$ emissions from microcosms and rice fields. Glob Chang Biol 9: 773-784.

Krüger M, Frenzel P, Conrad R. (2001). Microbial processes influencing methane emission from rice fields. Glob Chang Biol 7: 49-63.

Li J, Wang MX, Huang Y, Wang YS. (2002). New estimates of methane emissions from Chinese rice paddies. Nutrient Cycling in Agroecosystems 64: 33-42.

Liesack W, Schnell S, Revsbech NP. (2000). Microbiology of flooded rice paddies (Review). FEMS Microbiol Rev 24: 625-645.

Lilkanen A, Martikainen PJ. (2003). Effect of ammonium and oxygen on methane and nitrous oxide fluxes across sediment-water interface in a eutrophic lake. Chemosphere 52: 1287-1293.

Lu YH, Abraham WR, Conrad R. (2007). Spatial variation of active microbiota in the rice rhizosphere revealed by in situ stable isotope probing of phospholipid fatty acids. Environ Microbiol 9: 474-481.

Lu YH, Conrad R. (2005). In situ stable isotope probing of methanogenic archaea in the rice rhizosphere. Science 309: 1088-1090. 
Lu YH, Rosencrantz D, Liesack W, Conrad R. (2006). Structure and activity of bacterial community inhabiting rice roots and the rhizosphere. Environ Microbiol 8: $1351-1360$.

Ludwig W, Strunk O, Westram R, Richter L, Meier H, Yadhukumar et al. (2004). ARB: a software environment for sequence data. Nucleic Acids Res 32: 1363-1371.

Lueders T, Manefield M, Friedrich MW. (2004). Enhanced sensitivity of DNA- and rRNA-based stable isotope probing by fractionation and quantitative analysis of isopycnic centrifugation gradients. Environ Microbiol 6: 73-78.

Macalady JL, McMillan AMS, Dickens AF, Tyler SC, Scow KM. (2002). Population dynamics of type I and II methanotrophic bacteria in rice soils. Environ Microbiol 4: 148-157.

Mancinelli RL. (1995). The regulation of methane oxidation in soil. Ann Rev Microbiol 49: 581-605.

Manefield M, Whiteley AS, Ostle N, Ineson P, Bailey MJ. (2002). Technical considerations for RNA-based stable isotope probing: an approach to associating microbial diversity with microbial community function. Rapid Commun Mass Spectrom 16: 2179-2183.

McDonald IR, Murrell JC. (1997). The particulate methane monooxygenase gene pmoA and its use as a functional gene probe for methanotrophs. FEMS Microbiol Lett 156: 205-210.

McDonald IR, Radajewski S, Murrell JC. (2005). Stable isotope probing of nucleic acids in methanotrophs and methylotrophs: a review. Org Geochem 36: 779-787.

Miller LG, Sasson C, Oremland RS. (1998). Difluoromethane, a new and improved inhibitor of methanotrophy. Appl Environ Microbiol 64: 4357-4362.

Mohanty SR, Bodelier PLE, Conrad R. (2007). Effect of temperature on composition of the methanotrophic community in rice field and forest soil. FEMS Microbiol Ecol 62: 24-31.

Nold SC, Boschker HTS, Pel R, Laanbroek HJ. (1999). Ammonium addition inhibits ${ }^{13} \mathrm{C}$-methane incorporation into methanotroph membrane lipids in a freshwater sediment. FEMS Microbiol Ecol 29: 81-89.
Noll M, Matthies D, Frenzel P, Derakshani M, Liesack W. (2005). Succession of bacterial community structure and diversity in a paddy soil oxygen gradient. Environ Microbiol 7: 382-395.

Nouchi I, Mariko S, Aoki K. (1990). Mechanisms of methane transport from the rhizosphere to the atmosphere through rice plants. Plant Physiol 94: 59-66.

Pester M, Friedrich MW, Schink B, Brune A. (2004). pmoA-Based analysis of methanotrophs in a littoral lake sediment reveals a diverse and stable community in a dynamic environment. Appl Environ Microbiol 70: $3138-3142$.

Pol A, Heijmans K, Harhangi HR, Tedesco D, Jetten MSM, Op den Camp HJM. (2007). Methanotrophy below pH 1 by a new Verrucomicrobia species. Nature 450: 874-878.

Roslev P, Iversen N. (1999). Radioactive fingerprinting of microorganisms that oxidize atmospheric methane in different soils. Appl Environ Microbiol 65: 4064-4070.

Schütz H, Schröder P, Rennenberg H. (1991). Role of plants in regulating the methane flux to the atmosphere. In: Sharkey TD, Holland EA, Mooney HA (eds). Trace Gas Emissions by Plants. Academic Press: San Diego. pp 29-63.

Schütz H, Seiler W, Conrad R. (1989). Processes involved in formation and emission of methane in rice paddies. Biogeochemistry 7: 33-53.

Seiler W, Holzapfel-Pschorn A, Conrad R, Scharffe D. (1984). Methane emission from rice paddies. J Atmos Chem 1: 241-268.

Shrestha M, Abraham WR, Shrestha PM, Noll M, Conrad R. (2008). Activity and composition of methanotrophic bacterial communities in planted rice soil studied by flux measurements, analyses of pmoA gene and stable isotope probing of phospholipid fatty acids. Environ Microbiol 10: 400-412.

Vandenkoornhuyse P, Mahe S, Ineson P, Staddon P, Ostle $\mathrm{N}$, Cliquet JB et al. (2007). Active root-inhabiting microbes identified by rapid incorporation of plantderived carbon into RNA. Proc Natl Acad Sci USA 104: 16970-16975. 